\title{
Implementational Spaces of Language Policy in Indonesian Higher Education
}

\author{
Rosmaladewi \\ Politeknik Pertanian Negeri Pangkep \\ South Sulawesi, Indonesia
}

\author{
Amirullah Abduh \\ English Department, Faculty of Languages and Literature \\ Universitas Negeri Makassar \\ Makassar, Indonesia \\ amirullah@unm.ac.id
}

\begin{abstract}
The paper aims to describe the current policy of languages in Indonesia. The research investigates the features of implementational spaces in Indonesian language policy documents. Content analysis approach is used to analyze these policy levels. This policy research is inevitably important to build understanding and direction for a further investigation on the educational spaces and practice of language within Indonesian community particularly higher education
\end{abstract}

Keywords-Indonesia; language policy; implementational spaces; higher education

\section{INTRODUCTION}

Implementational spaces (IS) have become one of the important issues in language learning and language acquisition. IS related to the created environment and situations where people can engage, learn, and practice new language [1]. It also refers to how languages are used and the roles of language within the community and its social contexts.

Research on language and IS across the globe has been promoted by Hornberger [1] and Jonshon [2]. For example, the creation of continua of biliteracy and bilingualism was one of the examples of language implementation spaces. These authors believe that any language policy and practice may create and open up new implementational spaces, which the opportunities of teachers and practitioners to create any forms of practices that help learners to learn the language progressively.

In Indonesia, in our observations, none of research has been conducted related to implementation spaces within higher education. As a consequence, no information was provided related to IS. Therefore, this article will address this knowledge gap. This article aims to uncover the implementation roles of languages used in Indonesian higher education.

The term IS has been used by a number of studies concerning language policy and practices. The language policy on Andean countries truly opens up IS for educators (Hornberger, 2009) and the investigation on the US language policy fills up implementational spaces for teachers and practitioners in educational contexts [2]. These investigations concluded that IS provided educational benefits for language learners.

The IS is described by Johnson [2] as the "traces of language policy in the multilayered contexts of creation, interpretation, and appropriation". The multilayer contexts in Johnson research is examined via national policy, state policy and school policy settings. Each context expands the spaces for scholar and educators to create, adapt, interpret and apply language policy.

\section{METHOD}

The data presented in this paper is based on document analysis of five language policy documents. A content analysis approach is employed to isolate key themes that are discovered in the Indonesian government policy documents regarding the implementational spaces [3]. All the policies are publicly available either via electronic copies or printed copies. The key question is that how implementational spaces are stated in Indonesian policy documents?

\section{FINDINGS AND DISCUSSION}

The implementational spaces of language policy was represented in the context of the local, national and international languages in three aspects: as means of instruction in education, language for agreements, and scientific publications. The roles of Indonesian, foreign languages and local languages are depicted in the government and legislative policies in Table 1 below.

TABLE I. IMPLEMENTATION SPACES OF LANGUAGES IN INDONESIA

\begin{tabular}{|c|ccc|}
\hline Loles & IL & FL & VL \\
\hline Medium of instruction & +++ & ++ & + \\
Agreements & +++ & +++ & NA \\
Scientific publications & +++ & +++ & +++ \\
& & & \\
\hline
\end{tabular}


TABLE I CONT.

Note:

+++ : Obligatory

++ : Complementary

+ : Optional

NA: Not Available.

IL: Indonesian languages

FL: Foreign Languages

VL: Vernacular languages

\section{A. Medium of instruction}

According to the Laws on National Education System, No. 20 (2003) that Bahasa Indonesia must be used as the medium of instruction in higher educational institutions; "Bahasa Indonesia as a state language is used as medium of instruction in educational settings [4]. This legislative statement obliges all Indonesian tertiary institutions to set Indonesian as formal means of communication and instruction in educational settings. However, this does not include the foreign universities that are established as an international branch in Indonesian archipelago.

Foreign languages play major roles as complementary roles for the medium of instruction in educational settings. Even though the government policies do not specify the specific foreign languages can be used as means of instruction, English 'can' be used as for specific educational programs; Foreign language (e.g. English) can be used as medium of instruction for special education to support students' ability in foreign language [4].

In relation to vernacular languages, they can be used for early schoolings particularly those who are not fully exposed with the national language living in villages. It is clearly stated in one of the second verse of Article 33 in the National Education Acts: "Local languages can be used as means of instruction in early education if it is necessary to support the transfer of particular knowledge and skills [4].

However, local languages can be used for means of instructions in higher education especially for the major courses in local languages where many of universities have established school of languages.

\section{B. Memorandum of understanding (MoU)}

Bahasa Indonesia and foreign languages can be used for international agreements or Memorandum of Understanding (MoU). The higher education institutions are required to use Bahasa Indonesia as written language if it deals with domestic foundation or agencies. This is supported by the policy; "The Bahasa Indonesia has to be used for memorandum of understanding within domestic agencies" [5]

However, if it relates to the foreign countries or agencies, the national language of the partner countries or English has to be used for written language agreements. This shows stronger use of English compared to the Indonesian and local languages, as stated: The national language of partner countries or English are required to be used for international agreements [5]. Also English, we argue, becomes more like an additional language rather than foreign language for international agreement purposes. This explicit legislative statement shows stronger bilingualism policy rather than monolingual policy. This implied that every government/university officials particularly dealing with international matters are recommended to be bilingual officers which at least Indonesian and English.

\section{Publication purposes}

Scientific publications are required to use three languages (Bahasa Indonesia; foreign languages; and local languages, which are depending on purpose and contexts. The written publications for domestic purposes are compelled to use Bahasa Indonesia, as obviously written in the policy that Bahasa Indonesia has to be used for scientific writings and publications [5]

The publication of scientific research and papers for international journal is expected to be in foreign languages: Writing and publication for specific purposes can use local languages or foreign languages [5]). Despite it has no clear elucidation of which foreign languages, English is obvious language because it is the first foreign language in Indonesia and it is the official language of most internationally accredited journals around the world. Yet, there is no obvious borderline to the extent of the use of local languages particularly for the journals that are internationally recognized. It is clearly shown that journals and university publications that are globally accredited are compelled to use English.

In relation to 'foreign language' (bahasa asing), it is clear that this foreign language is mostly refer to English which is currently been using by whole sectors of Indonesian lifes and for several different purposes as explained above. Despite, there are other foreign languages taught as subjects in university courses, but it isn't used as a means of instruction yet. However, the law allows individuals to have multiple interpretations on the term 'foreign languages'. This is understandable since the law does not provide strict and clear guide on whether "foreign language' referring to English or other languages. As in line with the goal of Indonesian higher education that English can be used as medium of instruction for teaching and learning activities. This policy aims to drive universities in Indonesia to be internationally recognized

\section{CONCLUSION}

From these findings, the representation of language policies in Indonesia reflects implementational spaces (Hornberger 2004): medium of instruction, memorandum of understanding, and publication purposes. The implication is that it is important for the government to establish benchmark of the guidelines in applying implementational spaces within Indonesian multicultural contexts.

The arguments for internationalisation of higher education should not be the only basic reason for officially applying English as medium of instruction without prior well-planned programs for those who are involved in the international programs. 


\section{REFERENCES}

[1] N. H. Hornberger and S. McKay, Sociolinguistics and language education, vol. 18. Multilingual Matters, 2010.

[2] D. C. Johnson, "Implementational and ideological spaces in bilingual education language policy," Int. J. Biling. Educ. Biling., vol. 13, no. 1, pp. 61-79, 2010.
[3] M. Q. Patton, Qualitative evaluation and research methods. SAGE Publications, inc, 1990.

[4] Indonesia: Law No. 20, "National Education System." Ministry of Law and Human Rights, Jakarta, 2003.

[5] Indonesia: Law No. 24, "Flag, Languages, National Symbol, and National Anthem.” Ministry of Law and Human Rights, Jakarta, 2009. 